\title{
Integrated Geophysical Investigation of the Causes of Road Pavement Failure along Ibadan-Lagos Dual-Carriage, Southwestern, Nigeria.
}

\section{${ }^{* 1}$ LAYADE, GIDEON O; ${ }^{2}$ ADEGOKE JAMES A; ${ }^{2}$ OYEWOLE, IGE TEMITOPE}

\author{
${ }^{I}$ Department of Physics, Federal University of Agriculture, Abeokuta \\ ${ }^{2}$ Department of Physics, University of Ibadan, Ibadan \\ "layadeoluyinka018@gmail.com
}

\begin{abstract}
An integrated geophysical study has been conducted in a segment of IbadanLagos Dual-carriage road to examine the geological factors responsible for highway failure. Schlumberger Vertical Electrical Sounding (VES) and Very Low Frequency Electromagnetic Method (VLF-EM) to evaluate the subsurface integrity, mapping out the subsurface structural features within the sub-grade soil and delineating the bedrock relief as a means of establishing the causes of road pavement failure of $1300 \mathrm{~m}$ stretch of road from Ibadan axis. Results from VLF-EM showed the presence of near surface linear geologic structures from the surface to a depth of $15 \mathrm{~m}$ which suggests probable conductive zones that have devastating effects to the foundation of the road pavement (g1, g2 and g3). VES results showed the presence of four geologic layers while fractured basement were observed with resistivity value generally less than $100 \Omega \mathrm{m}$ which indicates the presence of the water table. The unstable segment is characterized by low resistivity of the near surface materials and shallowness of the aquifer zone on which the road pavement was constructed. The failure of the road is caused mainly by geologic sequence and structures such as clayey subgrade soil under the road pavement and some suspected geological features such as faults and fractures. CJASEM
\end{abstract}

\section{https://dx.doi.org/10.4314/jasem.v21i3.16}

Key words: Lithologic contacts, aquifferous zone, geoelectric section, linear contact, sub-grade soil

Man has come up with the art of proper designing, accessing and construction of structures, e.g. buildings, roads, tunnels, dams and bridges to suite his immediate needs and future purposes with the consideration for the competency of the soil over which they are built. All structures created on the earth's surface have its own substructures which are supported by the underlying rocks and soils (Adeyemo and Omosuyi, 2012).

Most problems of road failure can be associated with the failure of the contractors to adequately have the knowledge of the subsurface over which the road pavement is constructed, the physical parameters and geologic features governing the competency of the soil materials which bear the road pavement. Therefore, the nature of the soil or rock supporting road structure becomes an extremely important issue of safety, road integrity and durability. The geophysical factors influencing road failures include the nature of soils, the near surface geological structures such as fractures and faults, existence of ancient stream channels and shear zones (Hijab et al., 2012).
The collapse of concealed subsurface geological structures and other zones of weakness controlled by regional fractures and joint systems coupled with silica leaching which has led to rock deficiency are known to contribute to failure of highways (Nelson and Haigh, 1990). Ibadan-Lagos dual carriage is a major road connecting the western, eastern and northern parts of Nigeria, thus, it is a very busy federal highway. Several repairs have been done on different portions of the road over the years, but the road still fails persistently. A lot of reasons have been attributed to the incessant failure of roads in Nigeria: such as presence of expansive clays (Mesida, 1987), heterogeneity of the sub-grade materials (Adeleye, 2005 and Mesida, 1987), presence of undetected linear features such as fractures, faults and geological contacts (Momoh et al., 2008), poor construction practice and the use of substandard materials for road construction.

Objective: The objective paper is to investigate the main cause(s) of road failure along the stretch of Ibadan-Lagos dual carriage way using an integrated geophysical approach. 


\section{MATERIALS AND METHODS:}

An ABEM WADI electromagnetic equipment and Resistivity meter were used for data collection. Electromagnetic equipment was used for the reconnaissance survey, in order to measure the conductive zone along the road pavement. To measure the horizontal magnetic field component, the receiver coil automatically search to pick the VLF field with the phase control set at zero. A set of signal is picked up around any geologic body found from the primary signal of the transmitter. The signal strength of the transmitter ranges between 16.3 to $18.5 \mathrm{KHz}$.

An Electromagnetic (VLF-EM) survey was first carried out on the road pavement; a single traverse was established parallel to the road pavement for data collection. This method was employed as a reconnaissance tool to delineate possible hot spots along the road, the survey span through $1300 \mathrm{~m}$ along the road pavement out of which there are about 400 $\mathrm{m}$ of the stable portion of the road. The ABEM WADI electromagnetic equipment was used for data collection along the road segment. The VLF transmitter operating at a frequency of $18.6 \mathrm{KHz}$ was used for the survey. A $5 \mathrm{~m}$ station to station interval was adopted. The filtered real and filtered imaginary data were plotted against the station positions using KHFFILT software version 1.1a (Karous and Hjelts, 1983). A 2-D inversions of the real component data were obtained.

In the electrical resistivity method, vertical Electrical Sounding (VES) with Schlumberger electrode configuration was adopted. The field measurements were recorded with Abem Wadi Resistivity metre with maximum current electrode separation $(\mathrm{AB})$ of $110 \mathrm{~m}$ and $200 \mathrm{~m}$ in some areas. A total of 11 soundings was performed. Each sounding station was recorded in Universal Traverse Mercator coordinates with the aid of Global Positioning System (GPS). The soundings were performed parallel to the road pavement. The apparent resistivity measurements at each station were plotted against the electrode spacing $(A B / 2)$ on a log-log paper, partial curve matching were carried out for quantitative interpretation of the curves which give the number of layers, layer resistivity and thickness of each layer.

A qualitative interpretation was later performed using forward iterating modelled with the aid of RESIST VERSION 1.0 (Vander Velper, 1988). From the interpreted result, geoelectric sections were produced with the aid of surfer 10 software using the thickness of each layer and its corresponding resistivity value of all the soundings. The geological parameters obtained from the manual interpretation are considered acceptable at RMS error of $10 \%$ error level (Barker et al., 1996).

\section{RESULTS AND DISCUSSION:}

The results were presented as field curves, profile, geoelectric sections and VLF-EM 2-D inversion models.

Field Curves Results: The curve types identified within the study area ranges from $\mathrm{A}, \mathrm{H}, \mathrm{K}$, and $\mathrm{KH}$ curves. The number of layers varies from 3 and 4 , $\mathrm{KH}$ curve is the predominant curve (Table 1), constituting $37 \%$ of the total curve, $\mathrm{H}$ and $\mathrm{A}$ types constitute $27 \%$ each and $\mathrm{K}$ is just $9 \%$ of the total curves. Typical curve types in the study area are shown in figure 1 . The $\mathrm{KH}$ curve type as the predominant curve in the study area indicates that the area is being subdued by fractured basement.

Table 1: The Results of the Curve Matching

\begin{tabular}{|c|c|c|c|c|c|}
\hline VES No & Resistivity $(\Omega-m)$ & Thickness (m) & Remarks & Curve Type & $\begin{array}{c}\text { Number Of } \\
\text { Layers }\end{array}$ \\
\hline \multirow{4}{*}{1} & 62.2 & 0.3 & Topsoil & \multirow{4}{*}{$\mathrm{KH}$} & \multirow{4}{*}{4} \\
\hline & 86 & 3.2 & Weathered Layer & & \\
\hline & 53.1 & 8.6 & Partially Weathered/Fractured Bedrock & & \\
\hline & 139.1 & - & Fresh Basement & & \\
\hline \multirow{4}{*}{2} & 43.6 & 1.7 & Topsoil & \multirow{4}{*}{$\mathrm{KH}$} & \multirow{4}{*}{4} \\
\hline & 117.0 & 2.2 & Weathered Layer & & \\
\hline & 19.2 & 12.7 & Partially Weathered/Fracture Basement & & \\
\hline & 368.9 & - & Fresh Basement & & \\
\hline \multirow{3}{*}{3} & 59.4 & 0.7 & Topsoil & \multirow{3}{*}{ K } & \\
\hline & 199.8 & 9.2 & Weathered Basement & & \\
\hline & 130.8 & - & Fresh Basement & & 3 \\
\hline \multirow{3}{*}{4} & 120.3 & 0.7 & Topsoil & \multirow{3}{*}{$\mathrm{H}$} & \multirow[b]{3}{*}{3} \\
\hline & 61.3 & 1.9 & Weathered Layer & & \\
\hline & 146.0 & - & Fresh Basement & & \\
\hline
\end{tabular}




\begin{tabular}{|c|c|c|c|c|c|}
\hline \multirow{3}{*}{5} & 44.5 & 0.3 & Topsoil & \multirow{3}{*}{ A } & \multirow{3}{*}{3} \\
\hline & 109.2 & 22.6 & Weathered Layer & & \\
\hline & 401.8 & - & Fresh Basement & & \\
\hline \multirow{4}{*}{6} & 41.4 & 0.6 & Topsoil & \multirow{4}{*}{$\mathrm{KH}$} & \multirow{4}{*}{4} \\
\hline & 236.5 & 1.7 & Weathered Basement & & \\
\hline & 68.2 & 7.1 & Partially Weathered/Fractured Basement & & \\
\hline & 312.0 & - & Fresh Basement & & \\
\hline \multirow[b]{3}{*}{7} & 39.4 & 0.6 & Topsoil & \multirow[b]{3}{*}{ A } & \multirow[b]{3}{*}{3} \\
\hline & 59.0 & 10.7 & Weathered Layer & & \\
\hline & 333.5 & - & Fresh Basement & & \\
\hline \multirow{3}{*}{8} & 32.3 & 0.6 & Topsoil & \multirow{3}{*}{ A } & \multirow{3}{*}{3} \\
\hline & 65.2 & 11.9 & Weathered Layer & & \\
\hline & 397.0 & - & Fresh Basement & & \\
\hline \multirow{3}{*}{9} & 61.6 & 0.9 & Topsoil & \multirow{3}{*}{$\mathrm{H}$} & \multirow{3}{*}{3} \\
\hline & 37.3 & 3.9 & Weathered Basement & & \\
\hline & 212.5 & - & Fresh Basement & & \\
\hline \multirow{3}{*}{10} & 87.9 & 0.9 & Topsoil & \multirow{3}{*}{$\mathrm{H}$} & \multirow{3}{*}{3} \\
\hline & 49.6 & 11.3 & Weathered Layer & & \\
\hline & 280.1 & - & Fresh Basement & & \\
\hline \multirow{4}{*}{11} & 156.8 & 0.7 & Topsoil & \multirow{4}{*}{$\mathrm{KH}$} & \multirow{4}{*}{4} \\
\hline & 191.3 & 5.4 & Weathered Layer & & \\
\hline & 82.4 & 39.4 & Partially Weathered/Fractured Basement & & \\
\hline & 359 & - & Fresh Basement & & \\
\hline
\end{tabular}

The geoelectric section (figure 1) delineates four subsurface layers which are topsoil, the weathered layer, the fractured layer and the fresh basement at the most stable segment of the road. The topsoil has a resistivity value ranging from $32 \Omega \mathrm{m}$ to $120 \Omega \mathrm{m}$ corresponding to clay and clayey sand respectively; the topsoil thickness varies between 0.3 to $0.9 \mathrm{~m}$. The VLF-EM 2-D model (Figure 1) identified some linear features which display a fairly conductive medium, this can be seen along 550 to $650 \mathrm{~m}$ along the road pavement (yellow and red colour displays fairly and high conductive medium respectively). The identified linear feature along this road segment has a significant depth of about $9.3 \mathrm{~m}$. The stability of the road may have been due to the lateritic soil observed at the second layer (Akintorinwa et al., 2010) (Figure 1). The stable segment of the road is generally devoid of linear geological features such as fractures, faults, lithologic contact as it can be seen in figures 2-5 representing the raw and filtered measured data.

The basement relief presented in Figures 6-10 of the unstable segment (a) are generally uneven, with high depression at VES 3 (Figure 6). The VLF-EM 2-D model (Figure 7) identifies linear features having a depth extend to $2 \mathrm{~m}$ from the surface to about $25 \mathrm{~m}$ at the distance between $225 \mathrm{~m}$ to $260 \mathrm{~m}$, this can be indicative of geological features ( $g_{2}$ of figure 7 ) such as fractures and faults. The road failure along this segment may have been precipitated by a combination of conductive clayey subsoil, and network of near-surface and subsurface linear features suspected to be lithological contact such as faults, fractures and consequence absorbed by the clay topsoil. This lithological contact serves as weak zones that may increase the porosity and fluid permeability of the sub-soil and hence decrease the load bearing capacity of the road pavement (Adiat et al., 2009).

The unstable segment (b) (Figures 11 - 15) has clay at VES 9 and VES 10 at the upper thin topsoil with resistivity value generally less than $100 \Omega \mathrm{m}$ and clayey sand at VES 11 (Table 1). The underlying weathered layer is predominately clay at VES 9 and VES 10 with resistivity less than $100 \Omega \mathrm{m}$, and sandy clay at VES 11 with a resistivity value of $191.3 \Omega \mathrm{m}$ (Figure 11) with its basement relief uneven. Both the topsoil and weathered layer in the upper 0-12.1 $\mathrm{m}$ of segment (b) are composed of clay and sandy clay beneath the pavement with resistivity value generally less than $200 \Omega \mathrm{m}$ (Figure 11). The low conductivity of clay soil was revealed by the 2-D inversion model of VLF-EM, this was indicated by the red and yellow colour code in figure 12.

A suspected confined basement fracture is located between distance of $850 \mathrm{~m}$ to $1100 \mathrm{~m}$ in the 2-D model which shows high conductivity along the road 
pavement as this can be seen as red and yellow colour coding of the 2-D inversion model (Figure 12) and this falls within an intensively failed segment of the road. Fractured basement bedrock was delineated between distance of 900 to $1100 \mathrm{~m}$ on the geoelectric section (Figure 11). The drifting of water from the fractured basement can be absorbed by the clay topsoil, the contraction and expansion of clay can cause failure in the stability of the road pavement.

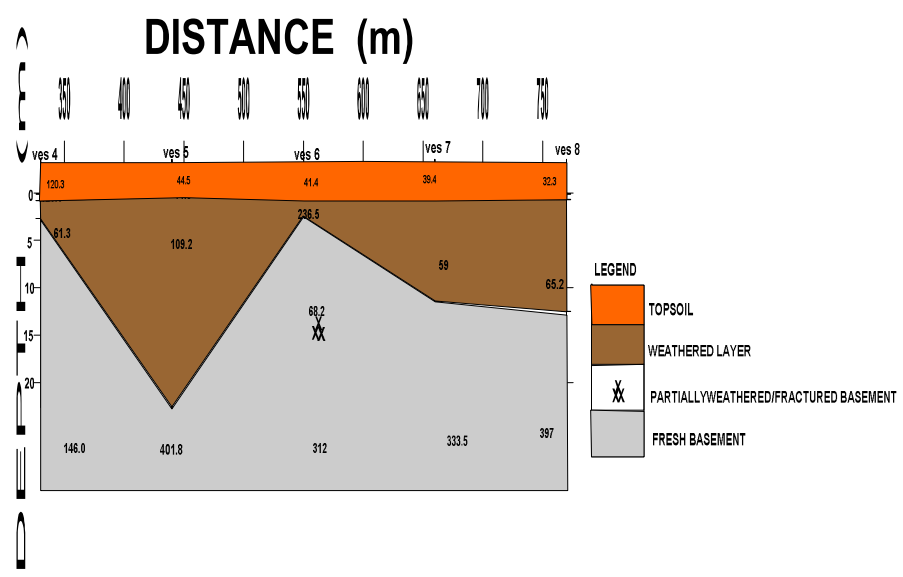

Fig 1 Geoelectric section of the stable segment
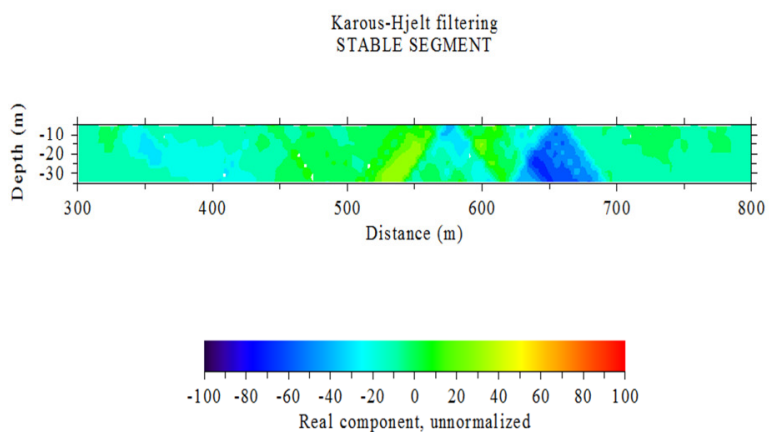

Fig 2: VLF-EM 2-D Inversion model of the stable segment

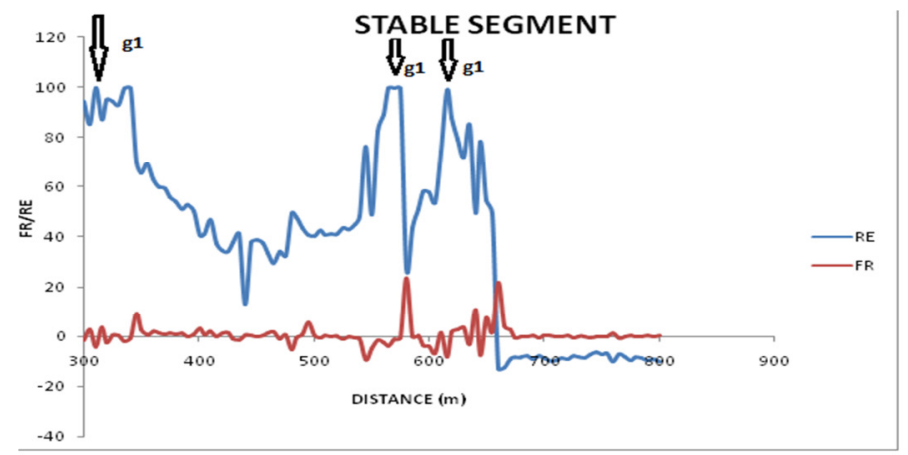

Fig 3:Graph of VLF-EM data (raw real and filtered real) of the most stable segment 
Fraser filtering

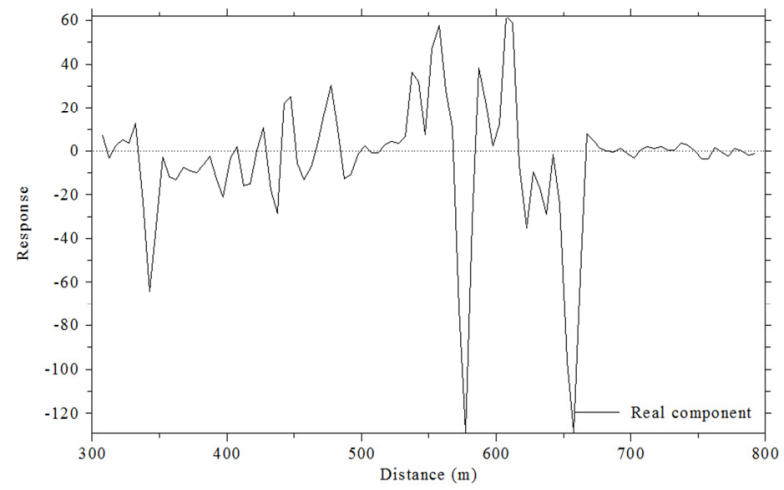

Fig 4:Fraser Filtering of the stable segment

VLF measurement

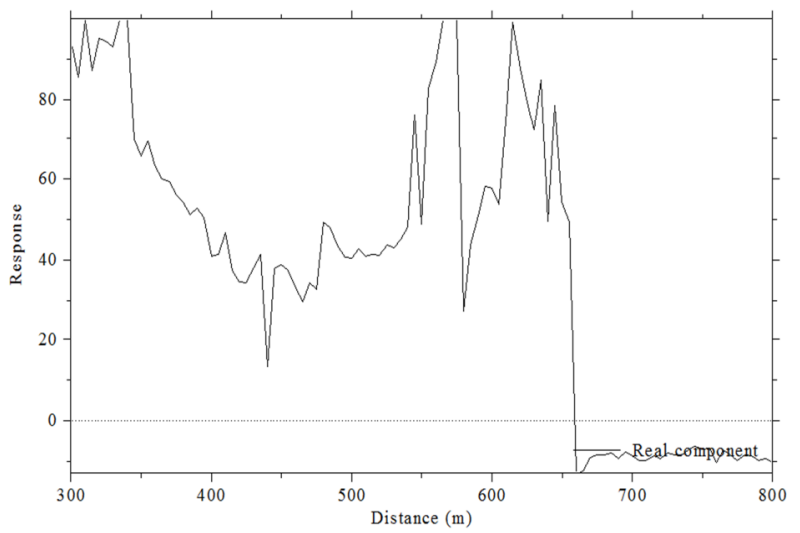

Fig 5: VLF measurement of the stable segment.

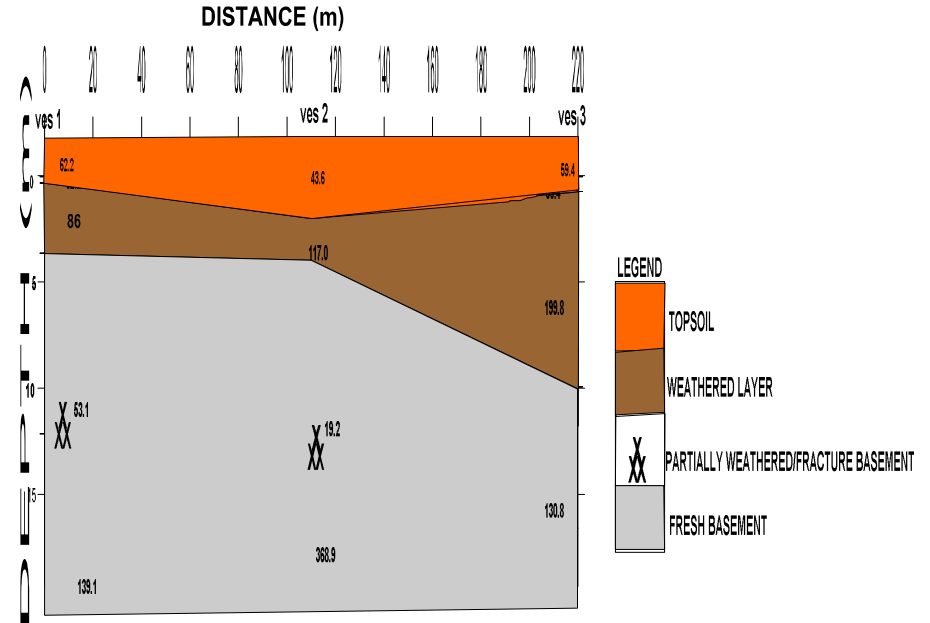

Fig 6: Geoelectric section of the unstable segment (a) 


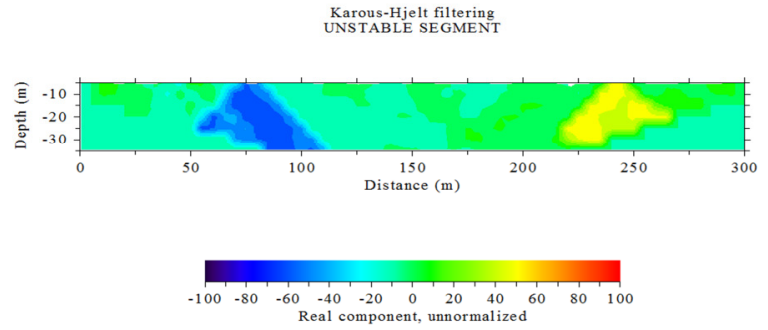

Fig 7: VLF-EM 2-D Inversion model of the unstable segment (a)

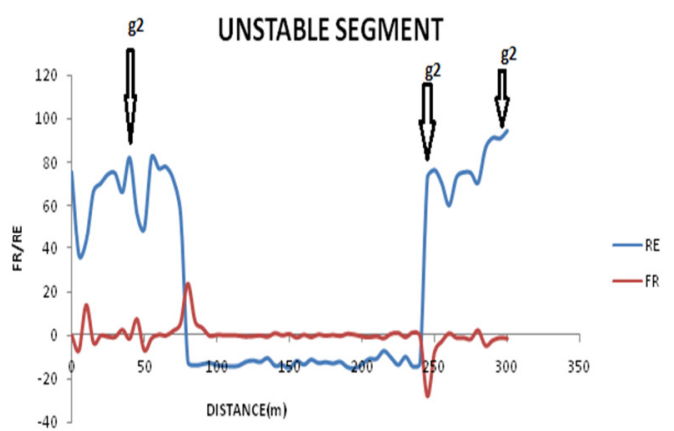

Fig 8: Graph of VLF-EM data (raw real and filtered real) of the unstable segment (a) Fraser filtering

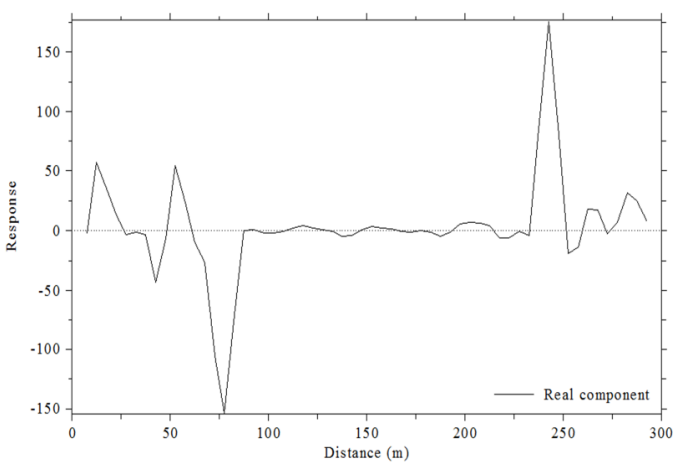

Fig 9:Fraser filtring of the unstable segment (a)

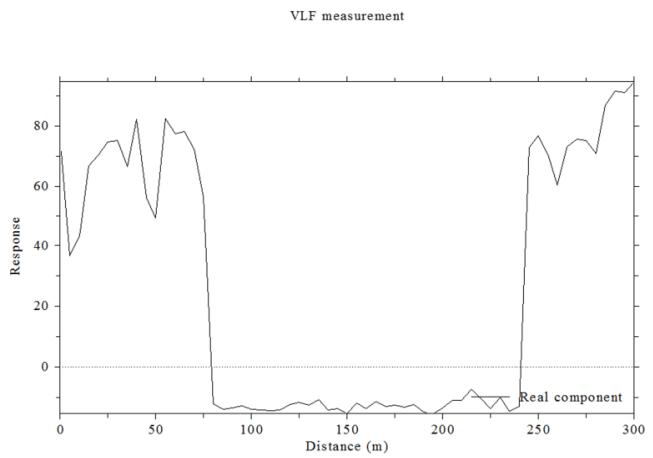

Fig10: VLF measurement of the unstable segment (a). 


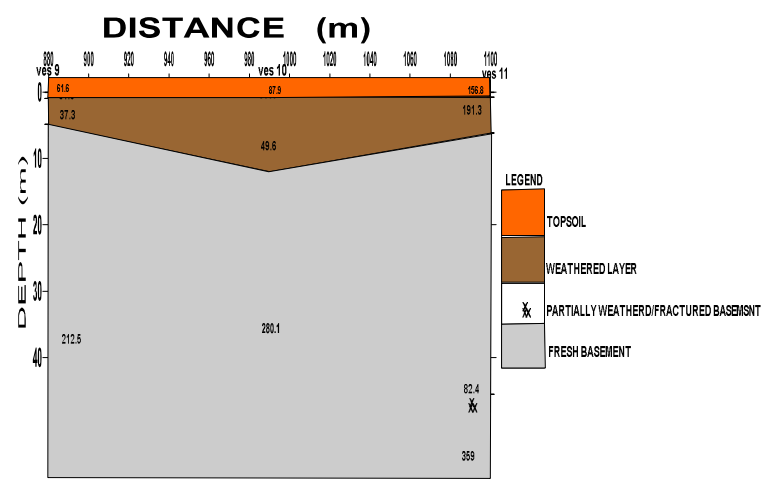

Fig 11: Geoelectric section of the unstable segment (b)

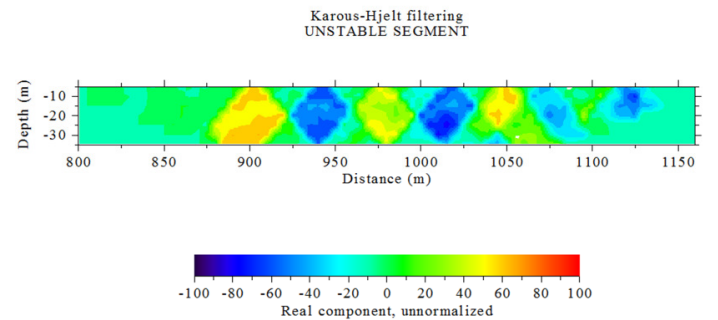

Fig 12: VLF-EM 2-D Inversion model of the unstable segment (b)

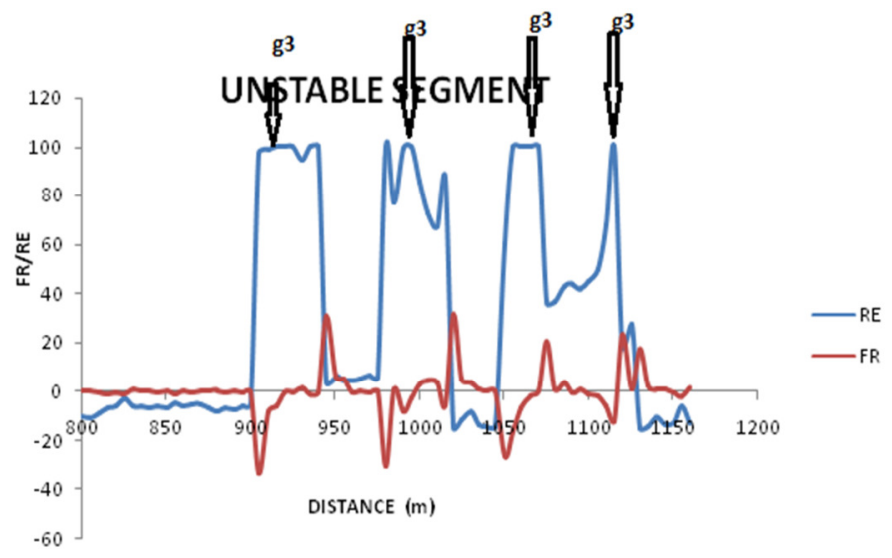

Fig 13:Graph of VLF-EM data (raw real and filtered real) of the unstable segment (b) Fraser filtering
UNSTABLE SEGMENT

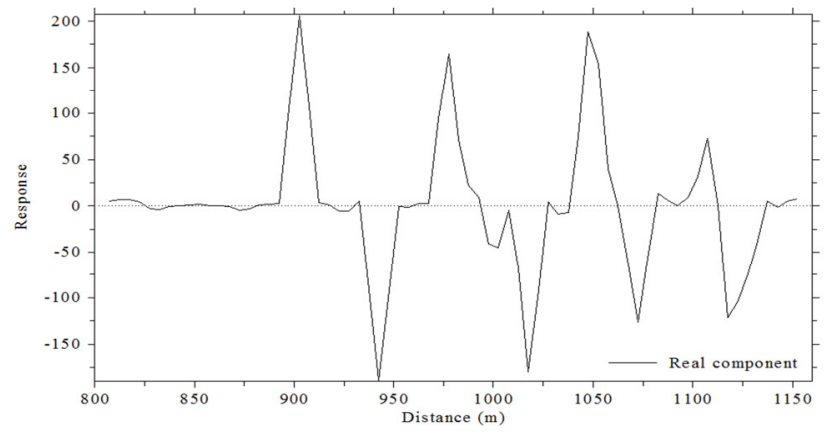

Fig 14: Fraser filtering of the unstable segment (b) 


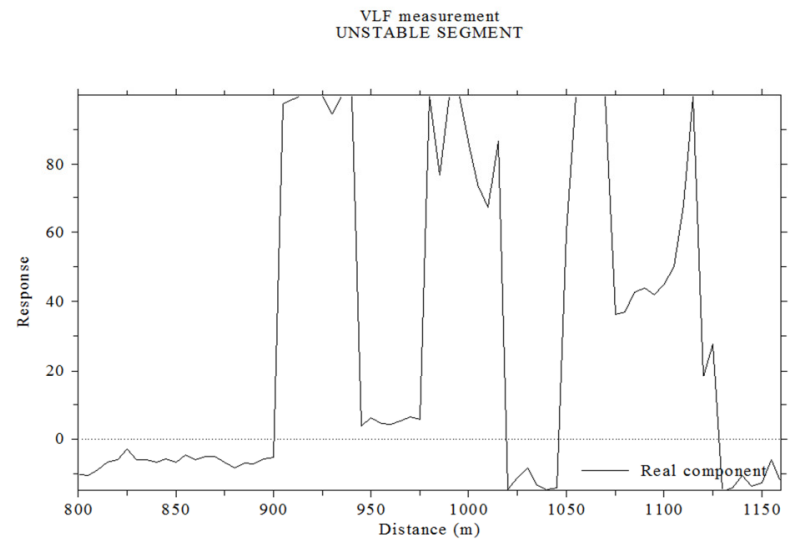

Fig 15: VLF measurement of the unstable segment (b).

Conclusion: The investigation revealed that, the topsoil and weathered layer are composed of clay and sandy clay formation and the fractured bedrock is linked to the lithology contacts whose high porosity and permeability allows the flow of water to the surface which can be absorbed by the clay at the topsoil. However, the road structural failure may also be caused by the use of substandard construction materials and unethical construction practices.

\section{REFERENCES}

Adeleye A. O. (2005). Geotechnical Investigation of Sub-soil Along Sections of Ibadan-Ile-Ife Highway Unpublished M.Sc. Project. Obafemi Awolowo University, Ile-Ife.181-192.

Adeyemo I. A. and Omosuyi G. O. (2012). Geophysical Investigation of Road Pavement Instability along Part of Akure-Owo Express way, Southwestern Nigerai. American Journal of Scientific and Industrial Research. 3(1), 191197.

Adiat K. A. N. Adelusi A. O. and Ayuk M. A. (2009). Relevance of Geophysics in Road Failures Investigation in a Typical Basement Complex of Southwestern Nigeria. Pacific Journal of Science and Technology. 5(2), 528539.

Akintorinwa O.J. Ojo J. S. and Olorunfemi M. O. (2010). Geophysical investigation of pavement failure in a Basement Complex Terrain of Southwestern Nigeria. Pacific Journal of Science and Technology. 11(2), 649-663.
Barker R. and Blunik I. (1996). Geophysical Consideration in Design, United Kingdom, National Resistivity Sounding Database; First Break. 14 (2), 45-53.

Hijab M. Zaynab A. B. and Hadi A. A. (2012). Road pavement Failure Induced by Poor Soil Properties Along Gombi-Biu Highway, Northern Nigeria. Journal of Engineering and Applied Science. (4), 22-28.

Karous M. R. And Hjelt S. E. (1983). Linear filtering of VLF Dip Angle Measurements Geophysical prospecting, England. 31, 782 - 794.

Mesida E. A. (1987). The Relationship Between The Geology and Lateritic Engineering Soils in The Northern Environs of Akure, Nigeria. Bulleting of the International Association of Engineering Geology. 2(3), 65-69.

Momoh I. O. Akintorinwa and M. O. Olorunfemi. (2008). Geophysical investigation of Highway Failure - A case study from the Basement Complex Terrain of Southwestern Nigeria. Journal of Applied Science Research, 4(6), 637 648.

Nelson R. G. and Haigh J. H. (1990). Geophysical Investigation of Lateritic Terrain. Geotechnical and Environmental Geophysics Ward, S. H $\left(3^{\text {rd }}\right.$ ed), (Geotechnical), SEG. (2), 133-154.

Vander Velper B. P. A. (1988). Resist Version 1.0, M.Sc. Research Project, ITC, Delf Netherland 